\title{
LABOR'S INTEREST IN GROUP INSURANCE
}

\author{
M. H. Hedges*
}

All insurance may be regarded as being based upon a social principle, namely, mutual aid. Moreover, insurance employs the civilized expedient of foresight for it is dependent upon present temporary deprivation in order that a greater loss may not be suffered in the future. "Whenever there is a contingency," said a report of the British House of Commons in 1825 on free societies, "the cheapest way of providing against it is by uniting with others so that each man may subject himself to a small deprivation in order that no man may be subjected to a great loss." This might be a description also of the device of coöperation utilized by labor unions, and it is no mystery why the insurance principle early attracted labor union leaders.

Group insurance is the most democratic form of insurance. It seeks to apply the principle of mutual aid to the greatest possible number at the lowest possible individual cost. In one sense, all insurance is group insurance; that is, individual contingencies must be muted and slowed by enveloping them in numbers. But group insurance, as a specialized department of insurance, has come to mean a blanket policy placed upon a given number of employees on a year-to-year basis. The first recorded policy was in IgII. Since that time, group insurance has had a rapidly developing career deploying from two angles: first from the employer's and second from labor's. In the labor field group insurance has evolved out of earlier and, in some respects, less scientific forms of insurance. It may be useful to trace the major stages of that evolution:

r. The insurance principle had its inception in the natural channel of humane impulses of labor unionists associated together who wished to give decent burial and to provide for families of deceased members. This was usually accomplished by the primitive method of "passing the hat" and taking up contributions for the purpose stated.

2. Establishment of death benefits on a simple mutual fund basis. Usually the amount paid from this fund to deceased member's families did not exceed $\$ 300.00$.

3. Establishment of mutual benefit societies on a legal basis with proper reserve funds and actuarial records which paid to deceased member's families sums ranging from $\$ 300.00$ to $\$ \mathrm{I}, 000$.

*A.B., I9ro, DePauw University; M.A., x912, Harvard. Director of Research, International Brotherhood of Electrical Workers, Washington, D. C. Government member of the Code Authority of the Radio Broadcasting Industry; special consultant on labor relations for the Tennessec Valley Authority. Author of "Iron City," a novel; "Dan Minturn," a novel; "A Strikeless Industry." Contributor to magazines and the Encyclopedia of Social Sciences. 
4. Supplementing the mutual benefit insurance societies with the establishment of oldline legal reserve life insurance companies with A-I rating which write group insurance especially adapted to the needs of labor unionists and their families.

Group insurance has been the occasion of some friction between labor and the employer. Labor regarded the blanketing of great groups of employees in any given plant under a term policy as part of a welfare program of employers intended to offset the need of labor organization. Historically speaking, there is little doubt that the establishment of the early mutual benefit societies by labor unions suggested to large corporations the writing of group insurance on a blanket, involuntary basis for their employees and that the employers' action in turn stimulated labor unions to found old-line legal reserve life insurance companies which could write the type of group insurance adaptable to labor union behavior. The interaction of these two solvents brings about present-day developments in the group insurance field which are characterized by changing types of groups for which policies are written. In addition to the employer type of group insurance and the strictly union type of group insurance, policies have been written for medical societies, fraternal lodge groups, trade associations, coöperative clubs, municipal employees, and even social clubs in rare instances.

In addition, one old-line legal reserve life insurance company has developed a family group policy which covers wives, children and relatives of members of any given union. This policy is written on a group life basis without medical examination and sold by mail. In some instances whole families are insured in this way.

Early in this development of labor group insurance it was evident that a liberalized group policy must be developed. It was necessary to protect the insured worker who was subject to hazards of modern employment and who had to pass from employer to employer. In many cases, under such conditions the worker lost his insurance rights, when he lost his job, under group policies written by the company. Under the group policy written by the union, the worker, as long, as he is a member of the union, no matter where he works, is still insured.

In 1933, 84 labor organizations paid death benefits of some kind. The total amount paid was $\$ 14,780,260.00 .^{1}$ On June 30 , I934, two labor old-line insurance companies had in force $\$ 96,178,400.00$ worth of group life insurance. ${ }^{2}$

In 1928 there were 75 hundred millions of dollars of group insurance throughout the United States. ${ }^{3}$ In 1934 there were 95 hundred millions (estimated).

Since group insurance in the labor field was a natural development from the earlier mutual aid insurance societies, it is important to consider in greater detail the reasons why labor came originally to embark on plans of mutual aid insurance.

\footnotetext{
${ }^{1}$ Report of the Executtve Council of the American federation of Labor to 54th Annual CoNvention (1934) 42 .

${ }^{2}$ By request, from Comptrollers of Union Labor Life Insurance Co. and Union Coöperative Insurance Association.

${ }^{3}$ U. S. Department of Commerce, Current Survey of Business.
} 
Labor unions were primarily organized to secure shorter hours, higher wages, and better working conditions for their members. Always behind these economic motives loomed more cultural aims. Insurance came to mean a practical instrument for the realization of higher aspirations of labor.

First, the mutual aid insurance society enabled the union to pay a higher death benefit than could be paid under the old plan of creating death benefit funds. In the second place, the payment of these death benefits was put into the hands of the members themselves and the entire business transaction was handled by their own chosen officers who automatically became the trustees of the insurance society. This meant that a certain and sympathetic construction of the contract and of the law in the consideration of each and every claim was given to the beneficiaries. In the third place, by utilizing the organization already in existence to collect the premiums and to handle the business of insurance, expenses and overhead were reduced to the lowest possible minimum. In the fourth place, the mere accumulation of funds under this form of insurance society became a source of strength and financial standing to the labor organization. In the fifth place, the establishment of mutual aid societies made possible the insurance of many workers who were engaged in extrahazardous occupations and who could not, for that reason, secure insurance from established companies. Finally, there was created machinery by which paying for the insurance on the part of the member was made easy and convenient. It was paid as part of the union dues so that it became almost painless.

At first, unions were averse to embarking upon mutual aid insurance plans, but when the membership had grown inured to paying the small premium of about 90 cents per month and beheld the swift payment of policies on death, they were won to this form of union activity. The union unexpectedly found too that it had achieved a form of cohesion in the organization itself and it had captured the allegiance of a great body of allied members hitherto indifferent to the policies of the unions, namely, the wives and relatives. The women who became the principal beneficiaries of insurance policies became bookkeepers for their husbands, and they themselves saw to it that union dues were paid regularly each month. The experience of the union in this regard differed, it appears, from the experience of many employers who embarked upon group insurance plans on an involuntary basis in their plants. The I929 report on Industrial group insurance published by the National Industrial Conference Board of New York states that "the sentiment of employers on the value of group insurance varies from enthusiastic approval to contention and disapproval of the whole scheme."

Two old-line insurance companies were established by union labor. First, there was the Union Coöperative Insurance Association, the instrumentality of the International Brotherhood of Electrical Workers, established in 1924. The second was Union Labor Life Insurance Company, an instrumentality of a number of unions of the American Federation of Labor, established in 1925. 
Both of these companies have sought to provide low-cost group insurance especially adapted to labor unions for those groups that have no mutual life insurance societies, or who wished to provide a much larger sum at death than the amount provided by the insurance societies. It is true also that ambitious plans were made to use the insurance principle to meet another form of misfortune and disaster, namely, unemployment.

Scores of local unions wrote blanket policies on their own members. In some instances a member received at death under the combined policies of the mutual aid insurance society and the group insurance $\$ 4,000.00$ or more.

Group life insurance policies were not developed by the old-line legal reserve life insurance companies of labor without difficulty. They found that the laws of many states did not permit the writing of that kind of policy which was developed, and they discovered that hostility developed in certain directions within the community against the insurance of certain union groups. It is worthwhile to examine the experience of union labor here inasmuch as it throws light upon the future of group insurance in this field.

The building construction industry is characterized by instability, heterogeneity, seasonal fluctuations, and a high financial mortality among the contractors who carry on the fiscal end of the business. This industry in the very best years affords an average of only about 200 working days per year to craftsmen employed. In bad years the craftsman is fortunate if he works 80 to Ioo days per year. As an experiment, union workers in certain principal industrial cities sought to bring about more favorable conditions for union members through working out with friendly contractors group insurance plans. In general, the arrangement called for the creation of a board of insurance trustees for a particular branch of the construction industry in a given city. The employer agreed to pay weekly to this board a premium based upon the per hour labor of every person working for such employer and carrying a union card. The special exception to this arrangement inhered in the fact that this payment did not apply to extra or additional work. The employers reported the work contracted for on forms provided for that purpose and remitted to the board payments by check or draft. A firm of certified public accountants was employed to set up a complete accounting system. The agreement further provided that the insurance board thus created should enter into insurance contracts with a legal reserve insurance company, providing in some instances group life insurance of $\$ 3,000.00$ for members, $\$ 40.00$ monthly pension for those of 65 years or over, and $\$ 30.00$ monthly for those totally disabled. The plan required the board to build up a working fund of its own as fast as conditions permitted so that during periods of depression when the normal work income was lessened the insurance benefits might be maintained. The plan provided that the board invest this working fund only in the best securities. It was found that hourly payments had to start in some instan̈ces at 20 cents per hour, but the plan was to reduce this hourly payment as rapidly as possible. In a 
number of cities the plan was not instituted early enough before the 1929 depression to escape the devastation wrought by that economic crash. Of the four large cities where the plan was instituted only one weathered the storm.

The plan, too, met with criticism. The indictment was that building costs were greatly increased and that the house-owners were being taxed heavily in order to maintain special privilege. Labor met these contentions by pointing out that any increase of 20 cents in the hourly wage scale of any union craftsman could not be reflected back vitally into building costs. And secondly, labor contended that all group insurance costs of firms or corporations, wherever or whatever they were, were ultimately paid by the consumer. It is likely that labor will approach industries as chaotic as the building construction industry with a good deal of misgiving hereafter as to whether any such group life insurance plan is feasible.

But group life insurance as worked out on a purely local union basis is a permanent feature of labor's economic program. Labor has come to look upon group life insurance as an instrumentality for creating an estate. It takes the position that the wage-earner not only has a right to a decent wage and a decent living, but he has the right, along with professional workers and business men, to build a reserve and to place his family, at his death, somewhat removed from the breadline. Starting with this premise the wage-earner undertakes to achieve the goal, as he has always done in the past, through the instrumentality of his union, in other words through economic coöperation. 